\title{
Oribatid mites (Acari, Oribatida) of yew, cypress and pine litter in southern Italy
}

\author{
STANISŁAW SENICZAK ${ }^{1}$ and ANNA SENICZAK ${ }^{2}$ \\ ${ }^{1}$ Department of Zoology, Kazimierz Wielki University, Ossolińskich 12, 85-093 Bydgoszcz, Poland \\ ${ }^{2}$ Department of Ecology, University of Technology and Life Sciences, Kordeckiego 20, \\ 85-225 Bydgoszcz, Poland \\ Corresponding author: Stanisław Seniczak, stseni@ukw.edu.pl
}

(Received on 29 March 2010; Accepted on 01 August 2011)

\begin{abstract}
Oribatid mite communities were investigated in southern Italy in litter under yew, pine and cypress trees. These mites achieved the highest density in yew and cypress litter in a park in the inland town of Caserta, and the lowest density in pine litter at the coast of Capo Vaticano. In these mite communities, only 1-4 species were abundant, so the Shannon index $H^{\prime}$ was rather low. The density of oribatid mites, species number, and dominance structure depended greatly on the kind of litter. The most abundant and common was Zygoribatula propinqua, but the highest density in yew litter was achieved by Oribatella superbula. In oribatid mite communities, the juveniles usually dominated, but the age structure of species greatly depended on the kind of litter.
\end{abstract}

Keywords: southern Italy, habitats, oribatid mites, population structure, juveniles

\section{INTRODUCTION}

Oribatid mites of southern Italy were investigated by several authors, but mainly in zoogeographical and faunistical aspects (BERNINI 1974a, b, 1977, 1978; BERNINI \& AVANzati 1983; Castagnoli et al. 1983; Bernini \& ArCidiaCono 1985; Bernini et al. 1995). This region is ecologically differentiated because of the southern Apennine Mountains, which run along the peninsula and slope in the direction of the Tyrrhenian Sea.

Coastal parts of southern Italy represent a typical Mediterranean climate, with hot and dry summer (June-September, mean day temperature $21-24^{\circ} \mathrm{C}$, total precipitation about $180 \mathrm{~mm}$ ) and cool and wet winter (October-May, mean day temperature $8-17^{\circ} \mathrm{C}$, total precipitation about $820 \mathrm{~mm}$ ), with about 300 sunny days per year. Hot and dry summers limit the density of oribatid species, but some species are adapted to such ecological conditions and achieve a high density and dominance index there. Therefore, these habitats are interesting for research on population characters of species, including their age structure. 
The density and species number of mites highly depend on vegetation (RAJSKI 1967, 1968), which is typical Mediterranean in the investigated regions [Castel del Monte (Apulia), Caserta (Campania) and coast of Capo Vaticano (Calabria)]. Arable fields are rather fertile, used for cultivation of wheat, sugar beet, and grape-vine or in higher parts for plantations of olive trees, grasses and herbs, often with groups of trees and bushes. In coastal tourist towns and villages, bitter orange, lemon, cypress, fig, and jacaranda trees are planted in gardens and along streets.

The aim of this paper was to investigate the soil oribatid mite communities in selected habitats of southern Italy: litter under yew, pine, and cypress trees. Special attention was paid to the age structure of dominant populations, which is rarely investigated in ecological papers.

\section{MATERIAL AND METHODS}

Samples of $500 \mathrm{~cm}^{3}$ each were taken on 1-7 July 2006, i. e. shortly after the relatively cool and wet spring. Samples were taken in 3 replicates from the following areas:

- park in Castel del Monte (Apulia) - litter under pine trees (Pinus sp.),

- park in Caserta (Campania) - litter under yew trees (Taxus sp.) and cypress trees (Cupressus sp.),

- coast of Capo Vaticano (Calabria) - litter under pine and cypress trees.

Mites were extracted from the samples in Tullgren funnels, next were preserved, and determined to species or genus levels, including the juveniles. In total, 6129 oribatid mites were investigated. The populations of oribatid species were characterized with the abundance $(A)$ and dominance $(D)$ indices, while the mite communities were compared with the Shannon index H' (ODum 1971). Names of oribatid species follow Subías (2004, online version, 2011) and partly WeIGMAnN (2006).

\section{RESULTS}

The investigated oribatid mite communities were rather abundant, with the highest density in the park in Caserta (yew and cypress litter), and the lowest values in pine litter at the coast of Capo Vaticano (Table 1). The richest in species were the mite communities in Caserta, while in the other habitats the number of species was lower, especially in pine litter on Capo Vaticano. Generally, in the oribatid mite communities, only 1-4 species were abundant, and therefore the Shannon index $H^{\prime}$ ' was rather low. Its highest value was recorded in cypress litter in Caserta, and the lowest value, in pine litter on Capo Vaticano.

The most abundant and common was Zygoribatula propinqua (Oudemans, 1900), but the highest density in yew litter in Caserta was achieved by Oribatella superbula (Berlese, 1904) (Table 2). Relatively abundant were also Arthrodamaeus reticulatus (Berlese, 1910) (yew litter and cypress litter in Caserta, cypress litter on Capo Vaticano), Cosmochthonius lanatus (Michael, 1885) (cypress litter on Capo Vaticano), and Oppiella nova (Oudemans, 1902) (cypress litter in Caserta).

Among oribatid mites the juveniles usually dominated, but the age structure of species depended greatly on the kind of litter (Table 3). For example, in cypress litter 
Table 1. Characteristics of oribatid mite communities in southern Italy: mean density (individuals per sample, i.e. $\left.500 \mathrm{~cm}^{3}, n=3\right)$, number of species, and Shannon index of diversity $\left(H^{\prime}\right)$

\begin{tabular}{lrrrrr}
\hline & $\begin{array}{c}\text { Castel del } \\
\text { Monte, litter }\end{array}$ & \multicolumn{2}{c}{$\begin{array}{c}\text { Caserta, } \\
\text { litter }\end{array}$} & \multicolumn{2}{c}{$\begin{array}{c}\text { Capo Vaticano, } \\
\text { litter }\end{array}$} \\
\cline { 2 - 6 } & \multicolumn{1}{c}{ Pine } & Yew & Cypress & Pine & Cypress \\
\hline Mean density of Oribatida & 158.7 & 877.7 & 555.7 & 73.3 & 267.3 \\
Mean density of juveniles & 93.0 & 440.3 & 310.7 & 37.3 & 157.0 \\
Number of species & 20 & 33 & 33 & 14 & 18 \\
Shannon index $H^{\prime}$ & 1.97 & 1.93 & 2.34 & 1.50 & 1.81 \\
\hline
\end{tabular}

Table 2. Characteristics of oribatid species in southern Italy: abundance $(A=$ individuals per mean sample, i.e. $\left.500 \mathrm{~cm}^{3}, n=3\right)$ and dominance $(D=\%$ of the total number of oribatid mites in the mean sample). Pin $=$ pine litter; $\mathrm{Cyp}=$ cypress litter; Yew $=$ yew litter. Species with maximum $A \leq 10$ are listed below the table

\begin{tabular}{|c|c|c|c|c|c|c|}
\hline \multirow{2}{*}{ Species } & & \multirow{2}{*}{$\begin{array}{c}\begin{array}{c}\text { Castel del } \\
\text { Monte, } \\
\text { litter }\end{array} \\
\text { Pine }\end{array}$} & \multicolumn{2}{|c|}{$\begin{array}{c}\text { Caserta, } \\
\text { litter }\end{array}$} & \multicolumn{2}{|c|}{ Capo Vaticano, litter } \\
\hline & & & Yew & Cypress & Pine & Cypress \\
\hline Achipteria nitens & $A$ & 0 & 44.3 & 45.0 & 0 & 0 \\
\hline (Nicolet, 1855) & $D$ & 0 & 5.1 & 8.1 & 0 & 0 \\
\hline Arthrodamaeus reticulatus & $A$ & 0.3 & 83.7 & 62.0 & 3.3 & 59.0 \\
\hline (Berlese, 1910) & $D$ & 0.2 & 9.3 & 11.2 & 4.4 & 22.1 \\
\hline Belba corynopus & $A$ & 0 & 16.6 & 11.0 & 0 & 0 \\
\hline (Hermann, 1804) & $D$ & 0 & 1.9 & 1.9 & 0 & 0 \\
\hline \multirow[t]{2}{*}{ Brachychthonius sp. 1} & $A$ & 6.3 & 3.3 & 67.3 & 2.0 & 1.0 \\
\hline & $D$ & 4.0 & 0.4 & 12.1 & 2.7 & 0.4 \\
\hline Cosmochthonius lanatus & $A$ & 0 & 0 & 0 & 1.3 & 92.0 \\
\hline (Michael, 1885) & $D$ & 0 & 0 & 0 & 1.8 & 34.4 \\
\hline Eueremaeus oblongus & $A$ & 0 & 7.7 & 18.0 & 0 & 39.0 \\
\hline (C. L. Koch, 1835) & $D$ & 0 & 0.5 & 3.2 & 0 & 14.6 \\
\hline Eupelops acromios & $A$ & 1.7 & 1.0 & 0.7 & 3.7 & 3.7 \\
\hline (Hermann, 1804) & $D$ & 1.1 & 0.1 & 0.1 & 4.9 & 1.4 \\
\hline E. occultus & $A$ & 0 & 0.7 & 24.7 & 0 & 0 \\
\hline (C. L. Koch, 1835) & $D$ & 0 & 0.1 & 4.4 & 0 & 0 \\
\hline
\end{tabular}




\begin{tabular}{lrrrrrr} 
Haplochthonius simplex & $A$ & 35.3 & 0 & 0 & 0.7 & 0 \\
(Willmann, 1930) & $D$ & 22.3 & 0 & 0 & 0.9 & 0 \\
Metabelba pulverosa & $A$ & 0.3 & 15.3 & 44.7 & 0 & 0.7 \\
Strenzke, 1953 & $D$ & 0.2 & 1.8 & 8.0 & 0 & 0.3 \\
Oppiella nova & $A$ & 0 & 0 & 63.3 & 0 & 0.2 \\
(Oudemans, 1902) & $D$ & 0 & 0 & 11.4 & 0 & 0.1 \\
Oribatella superbula & $A$ & 0 & 462.7 & 7.0 & 0 & 0 \\
(Berlese, 1904) & $D$ & 0 & 52.7 & 1.3 & 0 & 0 \\
Pilogalumna crassiclava & $A$ & 5.7 & 0 & 2.0 & 2.7 & 0 \\
(Berlese, 1914) & $D$ & 3.6 & 0 & 0.4 & 3.6 & 0 \\
Scheloribates initialis & $A$ & 3.7 & 0 & 0 & 4.3 & 0 \\
(Nicolet, 1855) & $D$ & 2.3 & 0 & 0 & 5.8 & 0 \\
Scheloribates pallidulus & $A$ & 6.0 & 75.0 & 0 & 0 & 17.7 \\
(C. L. Koch, 1840) & $D$ & 3.8 & 8.6 & 0 & 0 & 6.6 \\
Sphaerochthonius & $A$ & 1.0 & 22.7 & 0 & 8.0 & 2.7 \\
splendidus (Berlese, 1904) & $D$ & 0.6 & 2.6 & 0 & 10.7 & 1.0 \\
Tectocepheus velatus & $A$ & 12.3 & 18.3 & 0 & 0 & 0 \\
(Michael, 1880) & $D$ & 7.8 & 2.1 & 0 & 0 & 0 \\
Zygoribatula propinqua & $A$ & 65.3 & 8.3 & 159.0 & 46.0 & 39.7 \\
(Oudemans, 1900) & $D$ & 41.2 & 0.9 & 28.6 & 61.3 & 14.8 \\
\hline
\end{tabular}

Castel del Monte, pine litter: Camisia horrida (Hermann, 1804); Chamobates spinosus Sellnick, 1928; Malaconothrus sp. 1; Oppiella sp. 1; Peloptulus phaenotus (C. L. Koch, 1844); Peloribates sp.1; Protoribates sp. 1; Scheloribates laevigatus (C. L. Koch, 1835); Trichoribates trimaculatus (C. L. Koch, 1835).

Caserta, yew litter: Acronysus sp. 1; Ceratoppia bipilis (Hermann, 1804); Chamobates spinosus; Chamobates sp. 1; Eupelops sp. 1; Foremeaeus sp. 1; Licnodamaeus costula Grandjean, 1931; Microtritia minima (Berlese, 1904); Nothrus anauniensis Canestrini and Fanzago, 1876; Oppia denticulata (G. Canestrini and R. Canestrini, 1882); Oppiella sp. 1; Oribatella sp. 1; Oribatula tibialis (Nicolet, 1855); Phthiracarus sp. 1; Phthiracarus sp. 2; Protoribates sp. 1; Rhysortritia duplicata (Grandjean, 1953); Scheloribates laevigatus; Xenillus tegeocranus (Hermann, 1804); Zetorchestes falzonii Coggi, 1898.

Caserta, cypress litter: Acronysus sp.; Ceratoppia bipilis; Chamobates spinosus; Chamobates sp. 1; Damaeus sp. 1; Eupelops torulosus (C. L. Koch, 1840); Foremeaeus sp. 1; Gustavia fusifer (C. L. Koch, 1841); Hermaniella sp. 1; Licneremaeus licnophorus (Michael, 1882); Licnodamaeus costula; Microtritia minima; Nothrus anauniensis; Oppia denticulata; Oppiella sp. 1; Oppiella sp. 2; Oppiella sp. 3: Oribatella sp. 1; Oribatula tibialis; Phthiracarus sp. 1; Suctobelba sp. 1.

Capo Vaticano, pine litter: Aphelacarus acarinus (Berlese, 1910); Damaeus sp. 1; Dorycranosus acutus (Pschorn-Walcher, 1951); Galumna sp. 1; Neoliodes theleproctus (Hermann, 1804).

Capo Vaticano, cypress litter: Aphelacarus acarinus; Ceratoppia bipilis; Dorycranosus acutus; Minunthozetes semirufus (C. L. Koch, 1841); Oppiella sp. 2; Phthiracarus sp. 1; Scheloribates laevigatus; Trhypochthonius tectorum (Berlese, 1896). 
Table 3. Age structure of some oribatid species in southern Italy habitats: mean density (individuals per $500 \mathrm{~cm}^{3}, n=3$ ) of juvenile stages (Juv) and adults (Ad)

\begin{tabular}{llrrr}
\hline Name of species & Habitat & Juv & Ad & Total \\
\hline Achipteria nitens & Caserta, yew litter & 41.7 & 2.6 & 44.3 \\
& Caserta, cypress litter & 45.0 & 0.1 & 45.1 \\
Adrodamaeus reticulatus & Caserta, yew litter & 57.4 & 26.3 & 83.7 \\
& Caserta, cypress litter & 24.7 & 37.3 & 62.0 \\
& Capo Vaticano, cypress litter & 34.3 & 24.7 & 59.0 \\
Belba corynopus & Caserta, yew litter & 15.3 & 1.3 & 16.6 \\
& Caserta, cypress litter & 10.0 & 1.0 & 11.0 \\
Cosmochthonius lanatus & Capo Vaticano, cypress litter & 66.0 & 26.0 & 92.0 \\
Haplochthonius simplex & Castel del Monto, pine litter & 20.7 & 14.6 & 35.3 \\
Metabelba pulverosa & Caserta, cypress litter & 34.4 & 10.3 & 44.7 \\
\multirow{2}{*}{ Oribatella superbula } & Caserta, yew litter & 11.3 & 4.0 & 15.3 \\
Pilogalumna crassiclava & Caserta, yew litter & 200.7 & 262.0 & 462.7 \\
Scheloribates pallidulus & Caserta, yew litter & 8.3 & 0.7 & 9.0 \\
& Caserta, yew litter & 34.7 & 40.3 & 75.0 \\
Tectocepheus velatus & Capo Vaticano, cypress litter & 12.4 & 5.3 & 17.7 \\
& Castel del Monto, pine litter & 5.7 & 0.3 & 6.0 \\
Zetorchestes falzonii & Caserta, yew litter & 10.8 & 8.0 & 18.8 \\
Zygoribatula propinqua & Castel del Monto, pine litter & 0.7 & 11.6 & 12.3 \\
& Caserta, yew litter & 31.7 & 1.3 & 33.0 \\
& Caserta, cypress litter & 120.7 & 38.3 & 159.0 \\
& Castel del Monto, pine litter & 49.7 & 15.6 & 65.3 \\
& Capo Vaticano, pine litter & 28.0 & 18.0 & 46.0 \\
& Capo Vaticano, cypress litter & 20.7 & 19.0 & 39.7 \\
\hline \multirow{2}{*}{. } & & &
\end{tabular}

in Caserta, adults dominated in the population of Arthrodamaeus reticulatus, while in the nearby yew litter, juveniles of this species were more abundant. Populations of Zygoribatula propinqua were rich in juveniles, but in cypress litter on Capo Vaticano, juveniles were as numerous as adults. The population of Oribatella superbula was dominated by adults but with quite a large participation of juveniles (43.4\%). Many species were rich in juveniles, which in Metabelba pulverosa Strenzke, 1953 were 3-fold more abundant, in Belba corynopus (Hermann, 1804) were over 10-fold more abundant, while in Zetorchestes falzonii Coggi, 1898 were over 24-fold more abundant than adults.

\section{DISCUSSION}

The early summer communities of oribatid mites investigated in the present study were relatively abundant and rich in species, compared to the late summer populations on Rhodes Island (Greece) and in Andalusia (Spain) (SENICZAK \& SENICZAK 2006, 2010). This is probably due to better climate conditions, which are important 
for oribatid mites. In southern Italy the mites were sampled soon after the rather cool and wet spring, so the samples were relatively moist. Most oribatid mites in the Mediterranean climate develop intensely in winter and spring, but some species develop in summer (StAmou \& Sgardelis 1989). A high temperature and a low summer precipitation generally limit the development of soil animals (ATTENBOROUGH et al. 1989).

The density and species number of oribatid mites in the investigated habitats of southern Italy are comparable with those on the Croatian island of Korčula (SENICZAK et al. 2012), which is in a large part covered by forest trees and shrubs. Oribatid mites of open steppe vegetation of cape Tarkhankut in Crimea (Ukraine) were also relatively abundant, mainly due to the fresh sea breeze (SENICZAK et al. 2009), but the bushy patches distinctly increased the density of mites (SENICZAK et al. 2011).

The dominance structure of oribatid communities in the investigated habitats greatly depended on the kind of litter. In yew litter in Caserta, Oribatella superbula highly dominated, in cypress litter on Capo Vaticano Cosmochthonius lanatus was the most abundant, while in other habitats, Zygoribatula propinqua dominated. Oribatella superbula was recorded by BERNINI (1974) in several parts of Italy, but it was relatively numerous on Giglio Island in humus under shrubs and oak (Quercus ilex L.), under strawberry tree (Arbutus unedo L.), as well as in grasses, mosses, and humus near Tempio Pausania in Sardinia (Bernini 1983). Caruso \& Migliorini (2006) recorded it in small numbers in typical Mediterranean maquis (Quercus ilex L., Myrtus communis L., Arbutus unedo L., Pistacia lentiscus L., Phillyrea sp.) in the Castel Volturno Nature Reserve (southern Italy).

The genus Zygoribatula Berlese, 1916 occurs abundantly in Mediterranean region, and the juveniles usually dominate in populations of species. In this investigation $Z$. propinqua was the most abundant in cypress litter, while Z. glabra (Michael, 1890) was abundant in mosses covering the forest floor in Korčula island (SENICZAK et al. 2012). In habitats of Canary Islands (Spain), investigated by MorAZA \& PEÑA (2005a, b), the family Oribatulidae was most diverse family, with the most frequent $Z$. frisiae (Oudemans, 1900). High dominance indices of these species, in the light of THIENEMANN's (1939) principles, indicate a rather low soil fertility. The abundant juveniles of these species decompose soil organic matter quicker than adults (BERTHET 1963; StefaniaK \& SENiCZAK 1976), releasing the nutrients for plant growth. All species listed in Table 2 were recorded by BERNINI et al. (1995) from Peninsular Italy, except for Belba corynopus (Hermann, 1804), which is new for this region.

\section{CONCLUSIONS}

1. The oribatid mite communities of the investigated habitats were rather abundant, but the density of mites, species number, and dominance structure depended greatly on the kind of litter. Only 1-4 species were abundant there, so the Shannon index $H$ ' was generally low.

2. The most abundant and common was Zygoribatula propinqua, but in yew litter the highest density was achieved by Oribatella superbula.

3. In oribatid mite communities the juveniles usually dominated, but the age structure of species greatly depended on the kind of litter. 


\section{REFERENCES}

Attenborough D., Whitfield P., Moore P. D., Cox B. 1989. The atlas of the living world. Marshal Edition Ltd.

BERninI F. 1974a. Notulae Oribatologicae X. Oribatella ornata (Coggi) e due nuove specie ad essa affini (Acarida, Oribatei) [Oribatella ornata (Coggi) and two new species related to it (Acarid, Oribatei)]. Redia 55: 409-437 (in Italian).

BerninI F. 1974b. Notulae Oribatologicae XIII. La famiglia Oribatellidae (Acarida, Oribatei) nell'Arcipelago Toscano. (Studi sulla Riserva Naturale dell'Isolla di Montecristo, X) [Family Oribatellidae (Acarida, Oribatei) in the Tuscan Archipelago. (Studies on the Nature Reserve of Monte Cristo dell'Isolla, X)]. Lav. Soc. Ital. Biogeogr. N. S. 5: 429-504 (in Italian).

BERNINI F. 1977. Notulae Oribatologicae XVII. Nuovi dati sul genere Oribatella in Italia (Acarida, Oribatei) [New data on the genus Oribatella in Italy (Acarida, Oribatei)]. Redia 60: 457-505 (in Italian).

BerninI F. 1978. Notulae Oribatologicae XX. Il Genere Oribatella in Italia (Acarida, Oribatida) [The genus Oribatella in Italy]. Redia 6: 503-538 (in Italian).

Bernini F., AvanZati A. M. 1983. Notulae Oribatologicae XXIX. Le Oribatellidae (Acarida, Oribatida) viventi sul massiccio sardo-corso [The Oribatellidae (Acarida, Oribatida) living on the Corsica-Sardinia massif]. Lav. Soc. Ital. Biogeogr. N.S. 8: 347-400 (in Italian).

Bernini F., ARCidiacono R. 1985. Notulae oribatologicae XXXV. Some new records for the Oribatid Italian fauna (Acarida, Oribatida) and the description of the male of Hellenamerus ionicus (Mahunka). Animalia 12: 129-146.

Bernini F., Castagnoli M., Nannelli R. 1995. Arachnida, Acari. In: Checklist delle specie della fauna italiana, 24. Arachnida, Acari (Mineldi A., Rufo S., La Posta S., Eds) [Arachnida, Acari. In: Checklist of the Italian fauna species, 24. Arachnida, Acari], p. 1-131. Edizioni Calderini Bologna (in Italian).

Berthet P. 1963. Mesure de la consummation d'oxygene des Oribates (Acariens) de la litiere des forêts [Measurement of oxygen consummation of Oribatida (Acari) of forest litter]. In: Soil organisms (Doeksen J., Drift J. van DeR, Eds), pp. 18-31. North Holland Publ., Amsterdam (in French).

Caruso T., Migliorini M. 2006. Micro-arthropod communities under human disturbance: is taxonomic aggregation a valuable tool for detecting multivariate change? Evidence from Mediterranean soil oribatid coenoses. Acta Oecol. 30: 46-53.

Castagnoli M., Liguori M., Nannelli R. 1983. Gli Acari della polvere delle case in Italia [Dust mites in houses of Italy]. Atti 13 Congr. Naz. Ital. Entomol. Torino, p. 577-582 (in Italian).

Moraza M. L., PeÑa M. A. 2005a. Oribatid mites (Acari: Oribatida) in selected habitats of La Gomera (Canary Islands, Spain). Boln. Asoc. esp. Ent. 29: 39-54.

Moraza M. L., PeÑa M. A. 2005b. Oribatid mites (Acari: Oribatida) in selected habitats of Tenerife Island (Canary Islands, Spain). Bol. Soc. Ent. Aragonesa 1, 36: 285-291.

Odum E. P. 1971. Fundaments of ecology. W. B. Saunders Co., Georgia.

RAJSKI A. 1967. Autecological-zoogeographical analysis of moss mites (Acari, Oribatei) on the basis of fauna in the Poznan environs. Part I. Bull. Entomol. Pol. 37: 69-166.

RAJSKI A. 1968. Autecological-zoogeographical analysis of moss mites (Acari, Oribatei) on the basis of fauna in the Poznan environs. Part II. Fragm. Faun. 14: 277-405.

Seniczak S., Kaczmarek S., Seniczak A. 2009. Oribatid mites (Acari, Oribatida) of steppe vegetation on cape Tarhankut in Crimea (Ukraine). Biological Lett. 46: 43-49.

Seniczak S., Kaczmarek S., Seniczak A. 2011. Oribatid mites (Acari, Oribatida) of bushy patches in steppe vegetation of cape Tarkhankut in Crimea (Ukraine). Biological Lett. 48: 177-183.

Seniczak S., Kaczmarek S., Seniczak A., Graczyk R 2012. Oribatid mites (Acari, Oribatida) of some habitats of Korčula (Croatia). Biological Lett. 49: 27-34. 
Seniczak S., Seniczak A. 2006. The oribatid mites (Acari) of some habitats of Rhodes Island (Greece). Biological Lett., Poznań 43: 215-219.

Seniczak S., Seniczak A. 2010. Oribatid mites (Acari, Oribatida) of various habitats in southern Andalusia (Spain). Biological Lett. 47: 29-35.

Stamou G. P., Sgardelis S. P. 1989. Seasonal distribution patterns of oribatid mites (Acari: Cryptostigmata) in a forest ecosystem. J. Anim. Ecol. 58: 893-904.

Stefaniak O., SeniczaK S. 1976. The microflora of the alimentary canal of Achipteria coleoptrata (Acarina, Oribatei). Pedobiologia 16: 185-194.

Thientemann A. 1939. Grundzüge einer allgemeinen Oecologie [Principles of general ecology]. Arch. Hydrobiol. 35: 267-285.

Subías L. S. 2004. Listado sistemático, sinonímico y biogeográfico de los Ácaros Oribátidos (Acariformes, Oribatida) del mundo (1758-2002) [Systematic, synonymic and biogeographical check - list of the world's oribatid mites (Acariformes, Oribatida) (1758-2002)]. Graellsia 60: 3-305. Online version accessed in February 2011, p. 1-558; http://www.ucm.es/info/zoo/ Artropodos/Catalogo.pdf (in Spanish).

Weigmann G. 2006. Hornmilben (Oribatida) [Moss mites (Oribatida)]. In: Die Tierwelt Deutschland und der angrenzenden Meeresteile. 76. Teil (DAнL F., Ed), p. 1-520, Goecke \& Evers, Keltern (in German). 